\title{
"WE HEAR YOU, WE UNDERSTAND YOU" - USING VARK SURVEY TO UNDERSTAND FIRST YEAR LAW LEARNERS
}

\author{
Ani Munirah Mohamad ${ }^{1}$ \\ School of Law, Universiti Utara Malaysia (UUM), Malaysia \\ (Email: animunirah@uum.edu.my) \\ Anis Shuhaiza Md Salleh ${ }^{2}$ \\ School of Law, Universiti Utara Malaysia (UUM), Malaysia \\ (Email: shuhaiza@uum.edu.my) \\ Rafizah Abu Hassan ${ }^{3}$ \\ Faculty of Law, Universiti Teknologi Mara (UiTM), Malaysia \\ (Email: fiza@salam.uitm.edu.my)
}

Accepted date: $14-04-2019$

Published date: 17-07-2019

To cite this document: Mohamad, A. M., Md Salleh, A. S. and Abu Hassan, R. (2019). "We Hear You, We Understand You" - Using VARK Survey to Understand First Year Law Learners. International Journal of Modern Education, 1(1), 75-85.

DOI: $10.35631 /$ ijmoe. 11007

\begin{abstract}
With technological advancement and industrial revolution 4.0, teaching and learning, particularly in a higher learning institution, would definitely face challenges, not only to learners but also to teachers. One of the challenges faced by teachers is the learning styles of learners in this era. As learning styles and preferences may differ from one individual to another, understanding the learners is crucial so that the design and formulation of the teaching lessons, activities and assessment for the course would suit the learners' learning styles and meet the course learning outcomes. Hence, by employing a mixture of quantitative and qualitative methods, a VARK survey has been administered on 77 first-year law students of one higher learning institution in Malaysia to identify the learners' learning styles. Their preference in terms of how they learn best and what type of activities that suit them most for their learning process can be assessed. Considerably, the survey would assist the researchers in profiling the learners into groups based on their respective learning styles, particularly visual $(V)$, auditory $(A)$, reading/writing $(R)$ or kinesthetics $(K)$. This article emphasizes on the importance of understanding learners for any given course, generally, and harnessing the power of VARK survey in assisting the teachers to understand their learners better. Being able to understand the learning styles of the learners, the teachers would be able to structure and plan the teaching lessons to suit the styles of the learners. Consequentially, the learning objectives of the course would be met.
\end{abstract}

Keywords: Understanding Learners, Learning Styles, VARK Survey, Learning Preference

\section{Introduction}

Achieving the outcomes of learning courses along with the impartation of knowledge regarding the syllabus of a course are principally the roles of law educators in higher learning institutions. In order to develop the necessary proficiencies and know-how among the law students, 
educators would make learning the law a two-way communication which is captivating, real and current, a number of ways in teaching legal subjects will need to be employed. The educators of law must understand and be able to use methods of teaching which are best suited for learners of the law who have freshly transitioned from high school learning. Law students are expected to become analytical, dynamic and be able to think outside the box, and thus merged visual, auditory, reading/writing, kinaesthetic and tactile learning methods as a sample of modified learning style may need to be considered by law teachers (Sherr, et. Al. 2018).

However, the problem with the present way of lecturing is that it may not be suitable for all types of learners. It is suggested that lecturing the law by the antiquated way of a one-way discourse may no longer be a desired practice as it was in the old days (High, 2018). Educators must change their techniques and manner in which they teach and also their ability to support the learning process (Farrar, 2018). Therefore, education processes could be designed to cater to the students' learning inclinations. Literature have suggested that one way to know the learning styles of students is by adopting the 'VARK' survey, which essentially stands for: visual (V), auditory (A), reading/writing (R) or kinaesthetic $(\mathrm{K})$ learning preferences.

In this respect, this paper seeks to address the primary research question of: What are the learning styles of first year law students by engaging the VARK survey? Accordingly, the research objective of this paper is: To identify the learning styles of first year law students by engaging the VARK survey. Within the broader context, this paper would deliberate on the findings of the VARK survey of 40 first year law students in one higher learning institution in Malaysia. Recommendations are submitted at the end of this paper to enhance the relevancy and compatibility of legal studies in Malaysia. By such recommendations, teachers may be better assisted to adopt pragmatic educational and training contexts of legal studies by making known to them the information obtained.

\section{Literature Review}

This part discusses the key concepts engaged in this study, being the concepts of 'VARK survey', 'understanding learners' and 'learning styles. The relationship of the key concepts of the study are produced in the following Figure 1, representing the conceptual framework of the study.

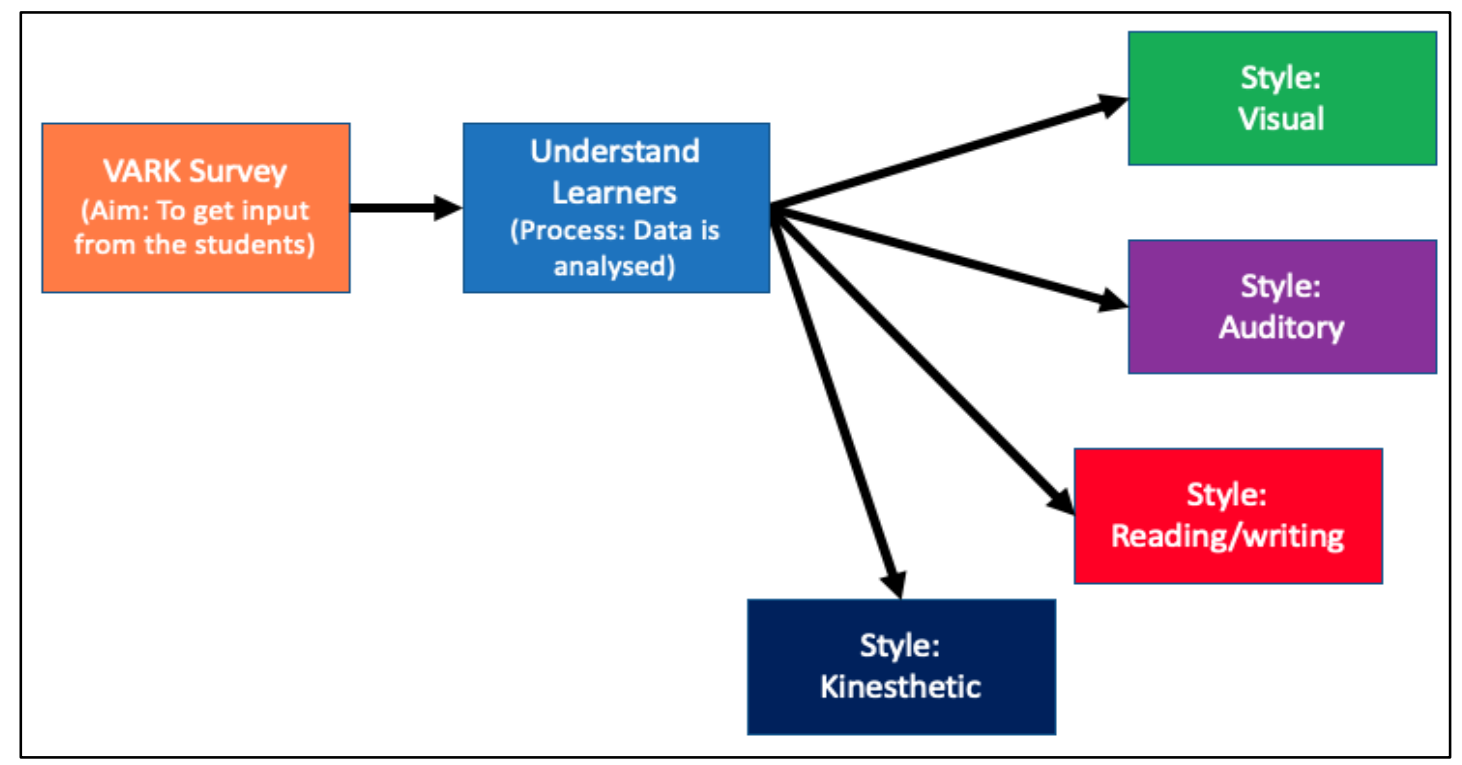

Figure 1. Conceptual Framework of The Study 


\section{VARK Survey}

The acronym "VARK" refers to visual (V), auditory (A), reading/writing (R) or kinaesthetic (K) learning preference of learners. Literature shows that knowing the learning preference of learners is important for teachers and learners. Hadi Peyman, et al (2014) concurred that it may affect the learning process and value of the information presented by teachers. In other words, knowing the manner in which a learner perceives thing, relates with, and reacts to the learning environment is necessary. Evidently, Akhlaghi N, et al (2018) stressed that the results of their VARK survey provide useful information for preparing a more problem-based curriculum with active learning strategies. In the same vein, Ojeh N, et al (2017) emphasised that the VARK tool was useful in gathering information about different learning styles, and might assist educators in designing blended teaching strategies to cater to the students' needs as well as help the students in becoming aware of their learning style preferences to enhance learning. In relation thereto, Sarabi-Asiabar A, et al (2014) advocated that knowledge about the learning styles of students at educational institutes is valuable and helps solve learning problems among students, and allows students to become better learners. From their research, it was revealed that male students preferred to use the kinaesthetic learning style more than females, while, female students preferred the auditory learning style.

\section{Understanding Learners}

Students come in various learning styles, which would essentially impact on their learning capabilities and preferences. DeGroff \& Mckee (2006) argued that individuals do differ to one another in the ways in which they choose to gather data, absorb and in how they process such data. Therefore, it is the responsibility of the teachers to understand their learners, so that ultimately, the course lessons, learning activities and assessment would be formulated to be consistent with the learning styles of the learners (Raturi, 2018). Accordingly, Simons, Harris and Smith (2006) suggested that approaches to learning that are promoted need to draw more extensively on processes which empower learners. They concurred that the ideas around learners and learning are critically important as they frame the actions of teachers and trainers in the sector to address what 'needs' and what constitutes quality teaching or training in the sector. In relation thereto, understanding learners is considered crucial by Alario-Hoyos, Estévez-Ayres, Pérez-Sanagustín, et al (2017) in their writing.

By employing Massive Open Online Courses (MOOC) as one of the learning strategies to address the needs of learners nowadays as there are neither timed face-to-face lectures, nor personalized tutoring with teachers. In the same vein, Kirkwood (2003) agreed that as educators, they need to develop a better understanding of learners by considering learners' attitudes and preferences in their studies. He advocated that using media technologies for teaching and learning process can provide many new educational opportunities, but are context dependent. Decisions about the extent to which students use particular media components are based at least as much upon the perceived benefits to be gained from them, as from any intrinsic characteristic or quality of the particular materials or resources.

\section{Learning Styles}

There are four major styles of learning of the learners, being visual, auditory, reading/writing and kinesthetics. The visual learning style is a way of learning in which information is associated with images. It requires that learners first see what they are expected to learn by means of charts, graphs, and pictures. (Abbas, 2012). Auditory learning style, on the other hand, is a way where learners retain information best when it is presented through sound and 
speech. (Abbas, 2012). This type of learners generally remembers their teachers' words and readily participate in class.

Meanwhile reading / writing learning style involves a situation where individuals are able to absorb and retain the most information through reading and writing text, as compared to imagery and symbolism. (Heidi and Stephen, 2005). This type of learners prefers to read lecture notes, writing essays and other information displayed in word and text form. Finally, kinesthetic learning is a process in which students learn by actively carrying out physical activities rather than by passively listening to lectures (Paolo and Scott, 2007). In other word, a kinaesthetic learning refers to learning process by physically engaging in classroom exercises (Steven, Wolfman and Rebecca, 2005). Learners of this style process information best when he or she is physically participated during the learning process.

\section{Research Methodology}

The research employs mixture of quantitative and qualitative methods in profiling the learners with the aim to understand them better, particularly in terms of their learning styles and learning motivations. Apart from that, the survey also explored the learners' expectations of the teachers, as well as what the learners would be willing to commit to enrich their own learning experiences.

For this purpose, an online survey was administered on 77 first year law students of one higher learning institution in Malaysia. The gender of the respondents is produced in Figure 2 below, with 15 respondents (19\%) are male learners, and $62(81 \%)$ are female learners.

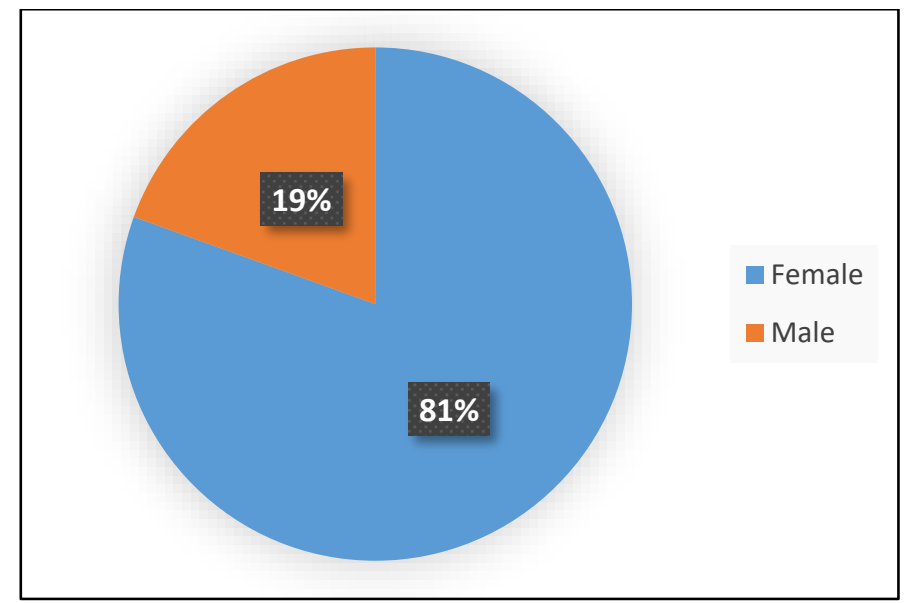

Figure 2: Gender of the Respondents

A breakdown of the race of the respondents is produced in Figure 3 below, comprising of 55 Malay respondents (72\%), 10 Indian respondents (13\%) and nine Chinese respondents (12\%) and. The remaining three respondents were one each (1\%) of Siamese, Iban and Punjabi races. Therefore, it is apparent that majority of the respondents were of Malay race, followed by Indian and Chinese races. 


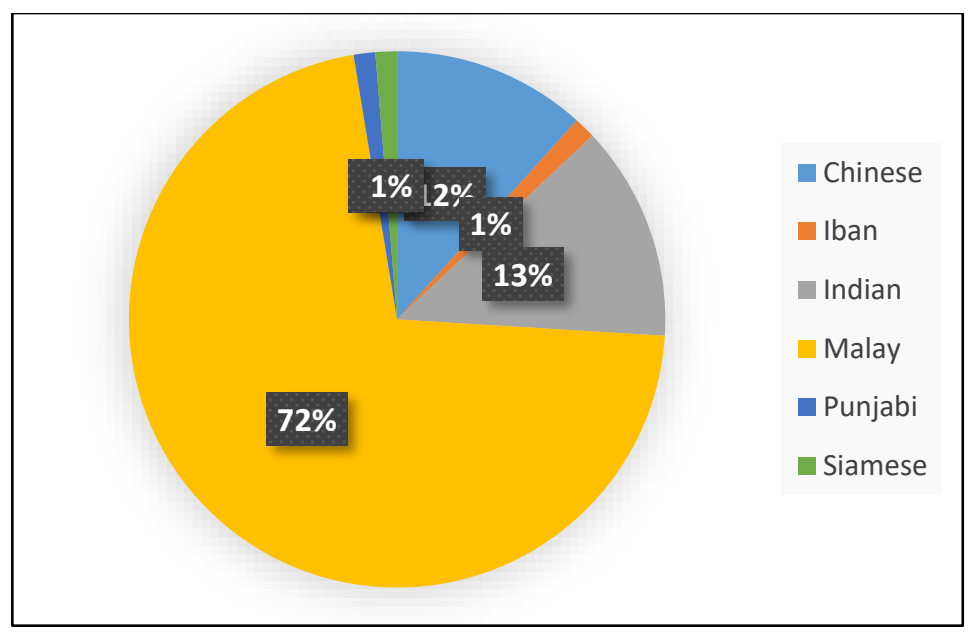

Figure 3: Race of the Respondents

The qualitative responses to the open-ended questions of the survey was analysed using the computer-aided qualitative data analysis software ATLAS.ti version 8.4 (Friese, 2019). The interface of ATLAS.ti is produced below in Figure 4. The choice for the usage of the ATLAS.ti software was made because it is appropriate for the purpose of data management and analysis qualitatively, and the process of making sense of the raw data could be achieved in a speedier manner as opposed to the manual method of analysis (Konopásek, 2007; Mohamad, 2014).

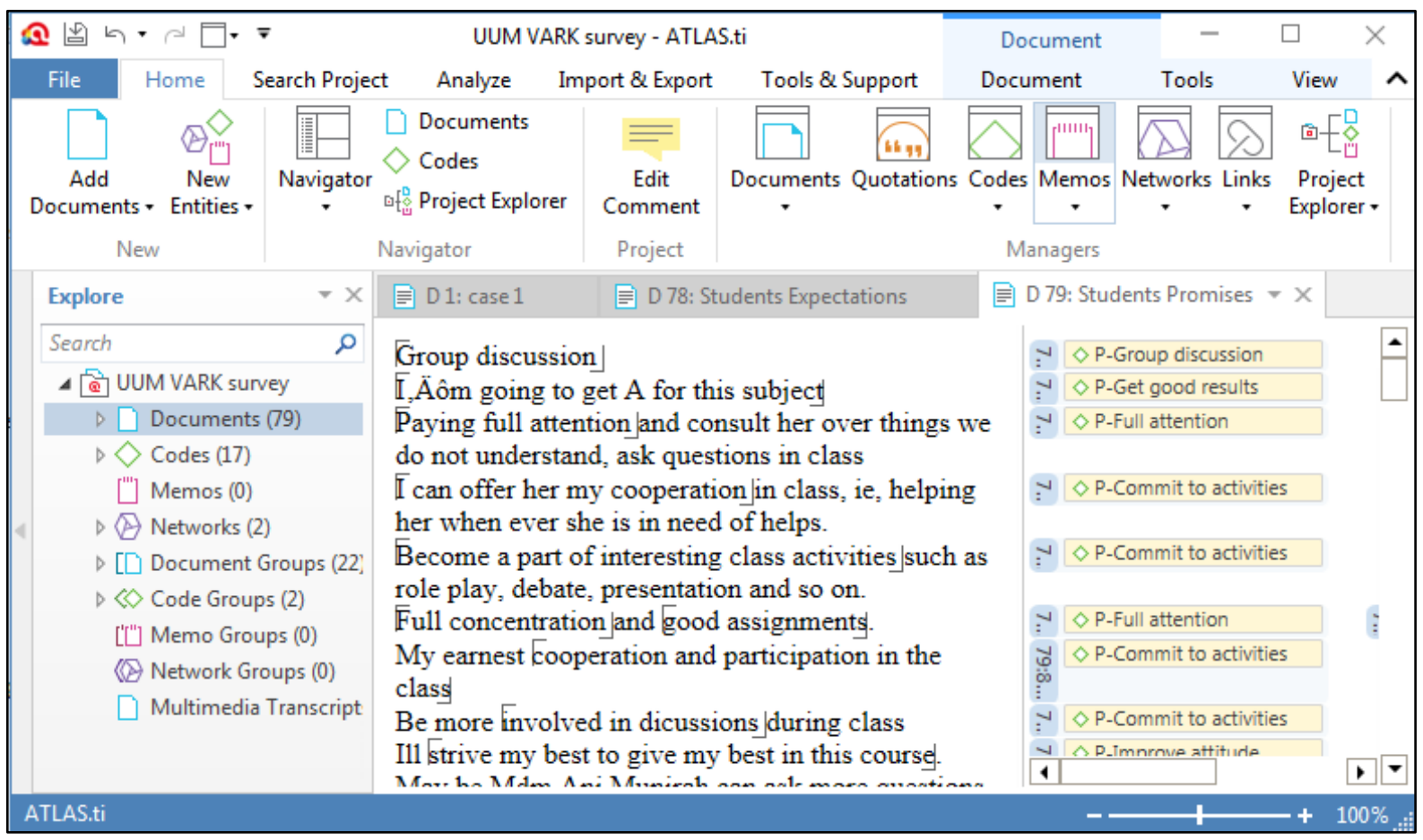

Figure 4: Interface of ATLAS.ti 8.4

In essence, the list of codes for the analysis was built using both deductive and inductive approaches for the purpose of reporting of the findings (Fereday \& Muir-Cochrane, 2006). The deductive approach was engaged primarily based upon the priori concepts found in the literature, such as 'creativity' and 'innovation. On the other hand, the inductive approach was used to capture the emergent concepts and ideas coming from the survey responses, such as 'sporting' and 'good results'. The list of codes built for the purpose of the study is shown in the Code Manager of ATLAS.ti in Figure 5. 


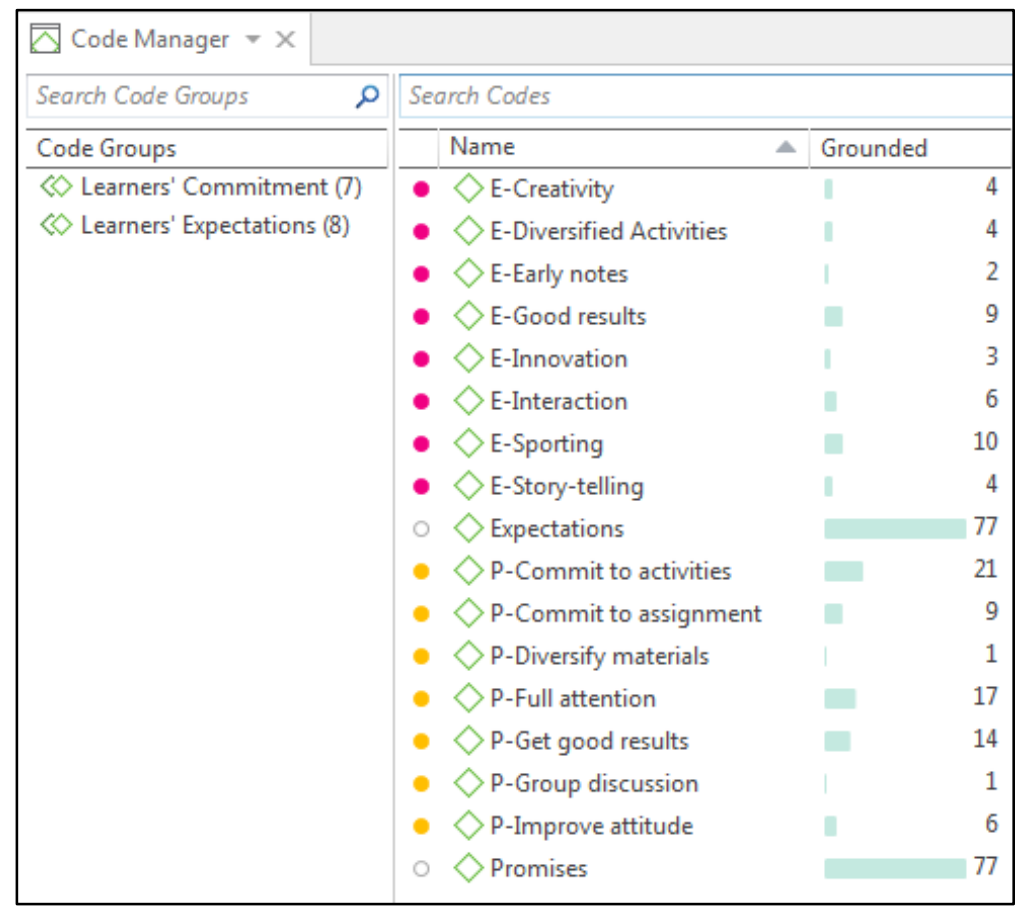

Figure 5: Codes list of the data analysis

\section{Research Findings}

The following findings could be derived from the survey data.

\section{Learning Styles}

The learning styles of the 77 learners were diversified, among three major ones being visual, kinesthetics and auditory. Most of the learners fall within the category of visual learners, because they learn best by utilising graphs, charts, maps, diagrams and others, being 37 learners $(48 \%)$ from the entire respondents. The second and third categories of learners are kinesthetic learners, where 26 respondents (34\%) stated that they learn best by way of doing, touching or manipulating materials, followed by audio learners, where 14 respondents (18\%) opted for learning by way of listening to the audio lessons. This finding is produced in Figure 6 below.

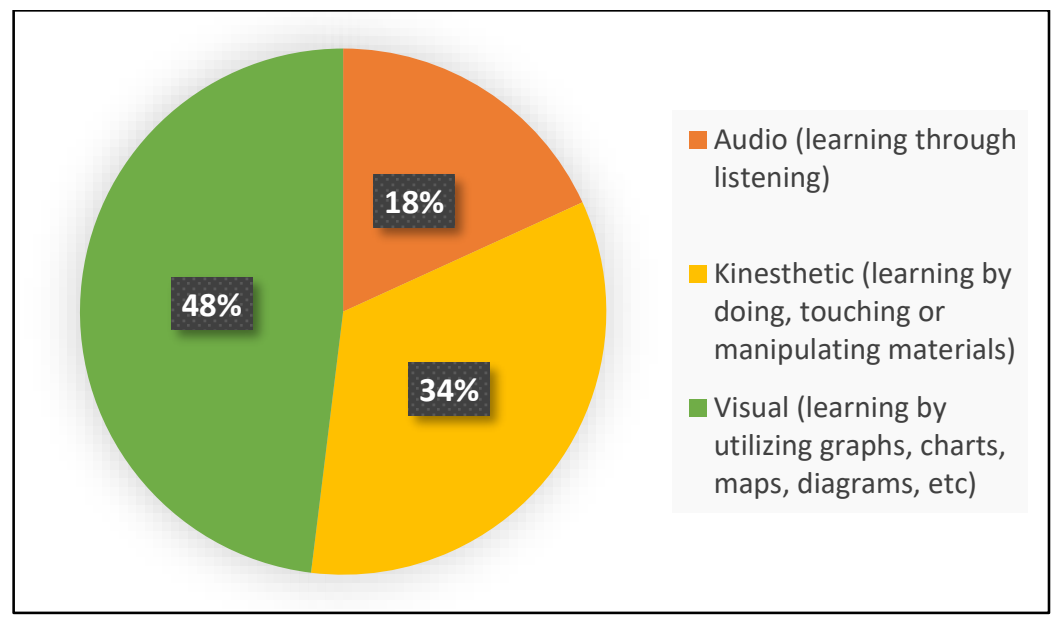

Figure 6: Learning Styles of the Respondents 


\section{Learning Activities Preference}

With regards to the preferred learning activities of the learners, 57 respondents (74\%) make up the majority of learners who prefer traditional lectures, 19 respondents (25\%) opted for activities in class, such as group discussion, games and roleplay. Finally, one respondent (1\%) preferred online learning. This finding is produced in Figure 7 below.

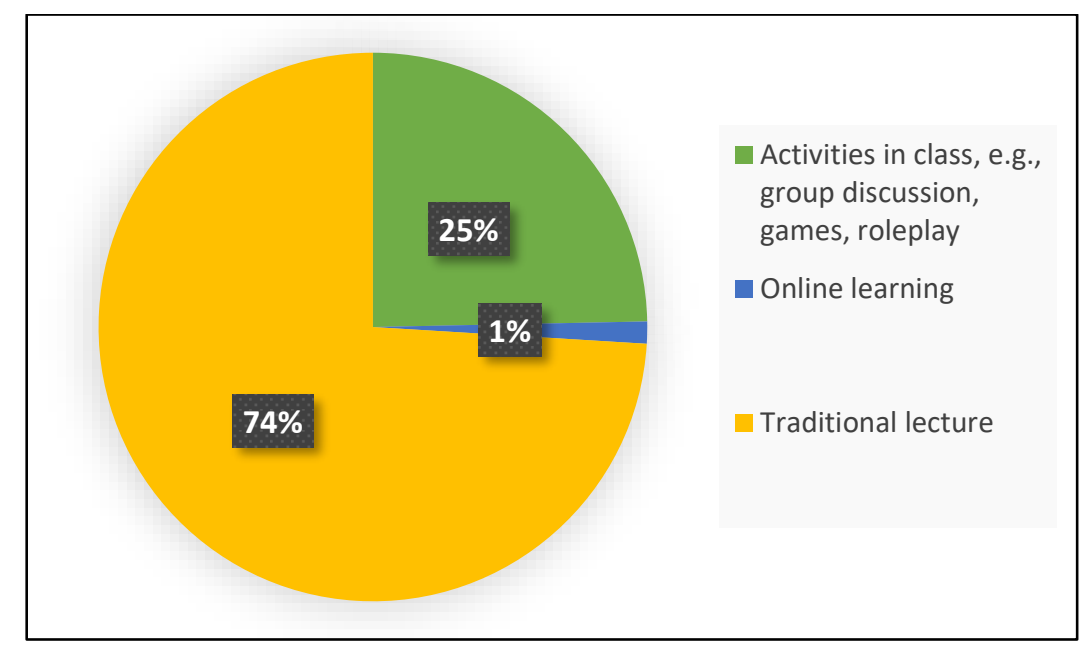

Figure 7: Learning Activities Preference of the Respondents

\section{Study Time Preference}

Learning can take place at different times of the day and night. As for the 77 survey respondents, $42(55 \%)$ stated that they learn best morning time, in between 8.30 and 11.30 am in the morning. Meanwhile, 25 respondents (32\%) stated that they prefer to study from midnight onwards, in between 12 midnight and 3 am in the morning. 8 respondents $(10 \%)$ stated that they learn best early morning time prior to official class times, in between 5 and 7 am. As for the afternoon classes, in between 1 and $6 \mathrm{pm}$, two (3\%) of the 77 respondents indicated that they prefer learning during this time. This finding is produced in Figure 8 below.

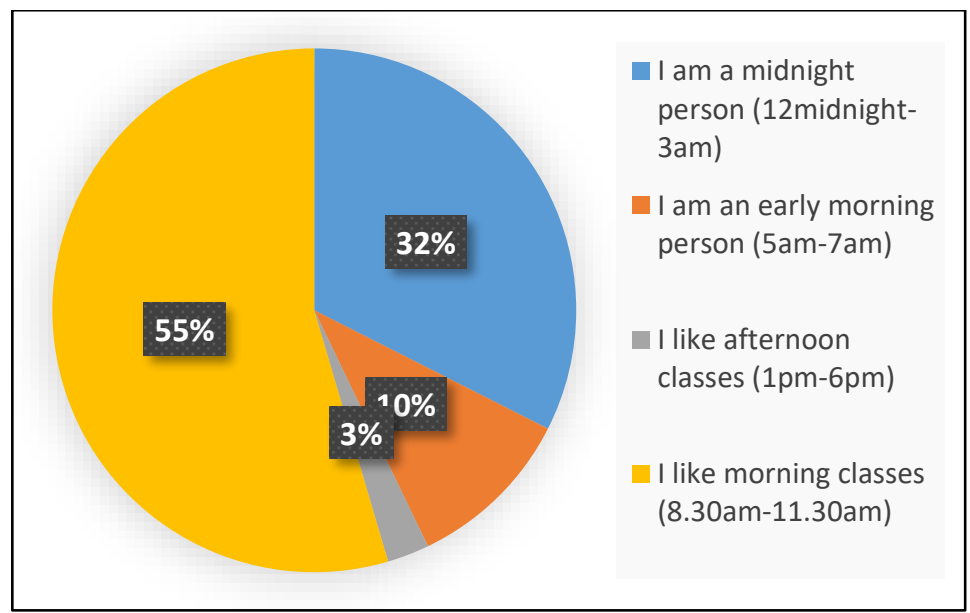

Figure 8: Study Time Preference of the Respondents

\section{Learning Factor}

Another question posted in the survey was intended to understand the learning factor that motivated the learners. 56 respondents $(73 \%)$ agreed that their learning factor is to become 
knowledgeable people. 18 respondents $(23 \%)$ indicated that they learn particularly to secure a good job in the future. Meanwhile, the remaining three (4\%) respondents agreed that they learn to satisfy the wish of their parents. This finding can be seen in Figure 9 below.

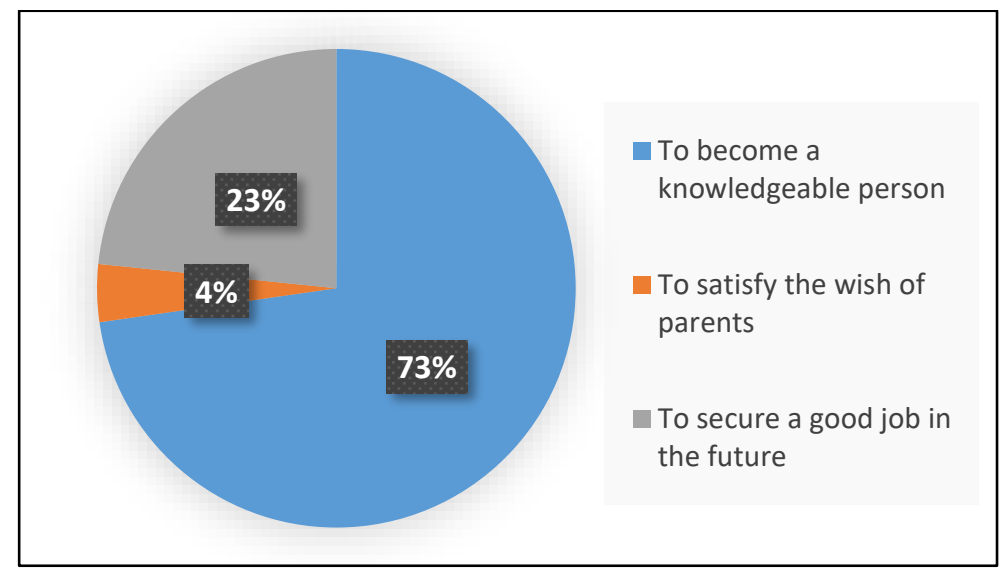

Figure 9: Learning Factor of the Respondents

\section{Learners' Expectations of the Teacher}

The first qualitative open-ended question of the survey enquired into the expectations of the teacher by the learners. The analysis of the open-ended responses to the question was conducted using qualitative analysis ATLAS.ti software and the findings highlighted eight main dimensions of the learners' expectations of the teacher, which could be summarized into the following Figure 10, which is a direct network output from the ATLAS.ti software.

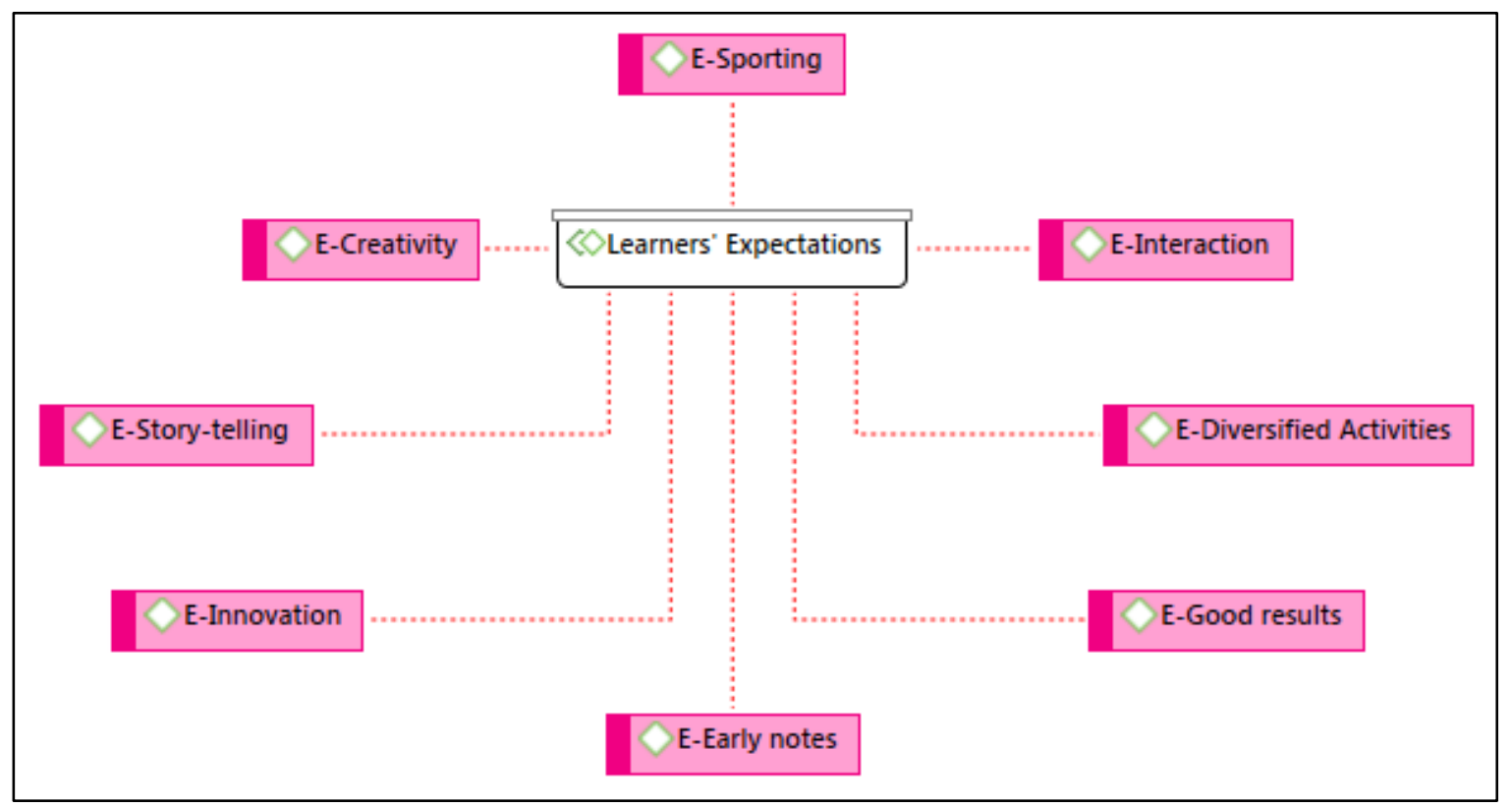

Figure 10: Learners' Expectations of the Teacher

Among others, the learners expect the teacher to be creative and innovative in delivering the teaching lessons in class, so that they would be happy and could understand the lessons better. Apart from that, the teacher is expected to encourage interaction between the teacher and the learners pertaining to the lessons of the subject. The learners also expect to undertake diversified activities in the classrooms, consistent with their expectations for the teacher to 
introduce creative and innovative approaches in the class. Moreover, one of the preferred approaches to be undertaken by the teacher is by way of story-telling, and sharing of the teacher's experiences, over and beyond what is contained in the teaching slides.

\section{Learners' Commitment to the Lessons}

The second and final survey question enquired into the learners' readiness and commitment towards enhancing their understanding of the lessons for the subject. In essence, this question served as the promises by the learners as to their commitment for the subject. Again, the data was loaded into and analysed in ATLAS.ti for the purpose of generating the report. The data revealed that there are seven dimensions of the learners' commitment to the lesson, as can be seen in the network output from ATLAS.ti in Figure 11 below.

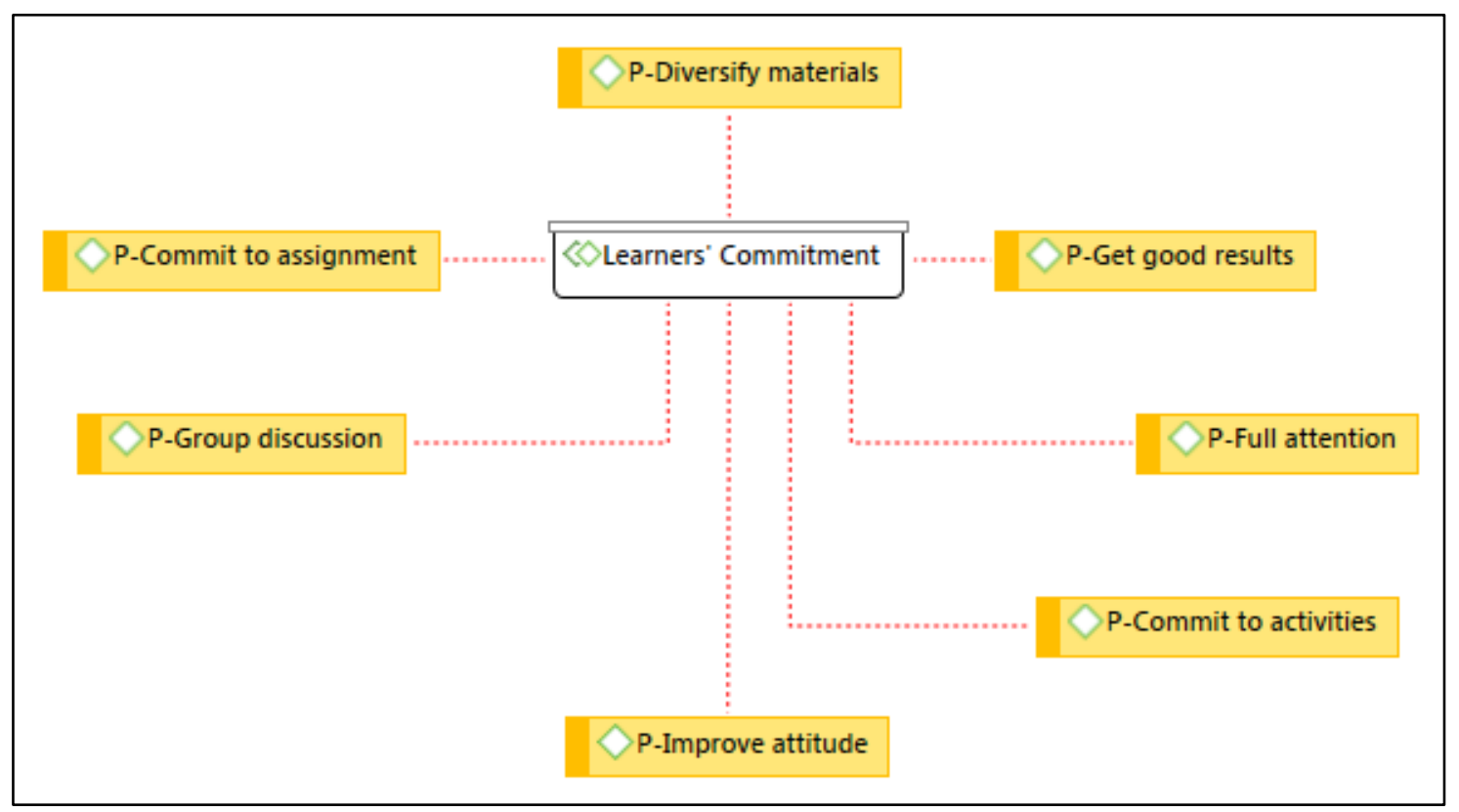

Figure 11: Learners' Commitment to the Lessons

First and foremost, the learners promised at the beginning of the semester to commit to activities introduced by the teacher during classes. To this, the learners also committed to render full attention to the lessons being taught by the teacher. Accordingly, the learners are committed to get good grades for this subject. Some others of the students promised to improve their attitude, which is a very good indication that they look forward to improving themselves for the purpose learning the lessons. One person also gave feedback that group discussion would be his/her strategy for better understanding the teaching lessons. And the last but not least, the data from the survey revealed that they would refer to diverse materials for the purpose of understanding the teaching lessons.

\section{Model for Understanding the Learners}

The significance for the teacher to understand the learners' learning styles, including the expectations and commitment to the lessons is that she/he could plan her teaching lessons to be consistent with the needs and expectations of the learners. At the same time, the teacher would also be mindful of the learners' promise to commit towards the subject, ultimately to ensure the achievement of the course learning outcomes for the subject. This flow of concepts is translated into the following model for understanding the learners as shown in Figure 112. 


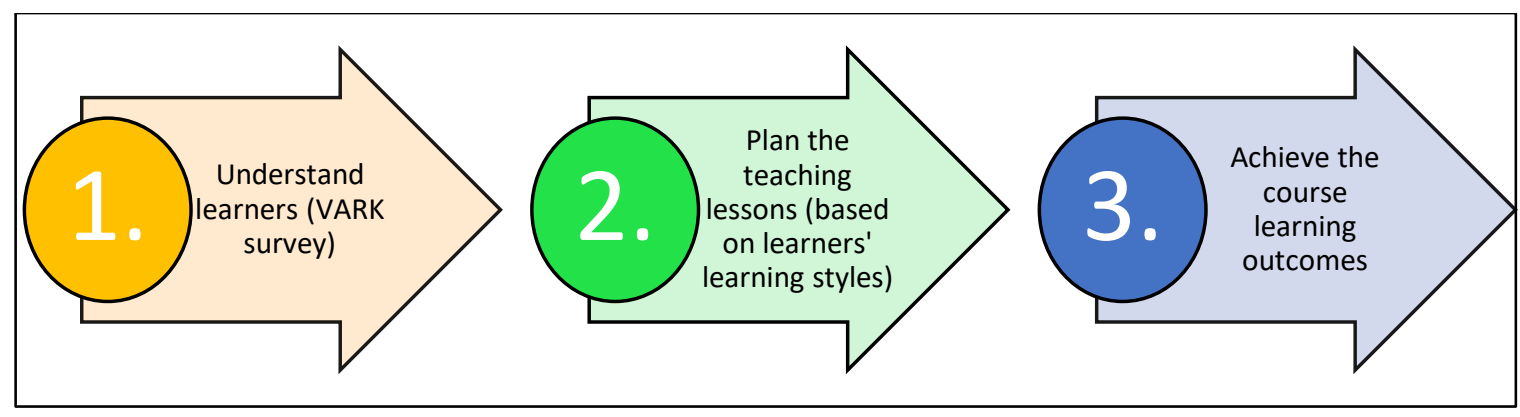

Figure 12. Model for understanding the learners

\section{Conclusion}

The aim of this paper is to demonstrate the process of identifying the learning styles of first year law learners by adopting the VARK survey due to the fact that it is crucial to achieve the learning outcomes for each and every course. The survey was found to be of great assistance in helping educators grasp the learning styles of the learners, and eventually design and prepare the teaching course modules, activities and appraisals to satisfy the respective learning styles. Thus, the survey could be duplicated for research in the future for learners from variant levels of programs and study. Lastly, such findings will assist educators to comprehend their learners better, more so in making sure that the specific courses' learning outcomes are realised. Future research could be directed to bigger sample with various specialisations of study, not only for law students. Further, focus could also be made at various stages on study, not only aimed at first year of studies.

\section{References}

Abbas Pourhossein Gilakjani. (2012). Visual, Auditory, Kinaesthetic Learning Styles and Their Impacts on English Language Teaching. Journal of Studies in Education, Vol. 2, No. 1, (2012), 104-113.

Adrian Kirkwood (2003) Understanding Independent Learners' Use of Media Technologies, Open Learning: The Journal of Open, Distance and e-Learning, 18:2, 155-175, DOI: 10.1080/02680510307412

Akhlaghi N, Mirkazemi H, Jafarzade M, Akhlaghi N. (2018). Does learning style preferences influence academic performance among dental students in Isfahan, Iran? J Educ Eval Health Prof. 2018 Mar 24; 15:8. doi: 10.3352/jeehp.2018.15.8. eCollection 2018.

Alario-Hoyos, C., Estévez-Ayres, I., Pérez-Sanagustín, M., Delgado Kloos, C., \& FernándezPanadero, C. (2017). Understanding Learners' Motivation and Learning Strategies in MOOCs. The International Review of Research in Open and Distributed Learning, 18(3). https://doi.org/10.19173/irrodl.v18i3.2996

DeGroff, Eric A. and Mckee, Kathleen A. Learning Like Lawyers: Addressing the Differences in Law Student Learning Styles, 2006 BYU Educ. \& L.J. 499 (2006). Online, available at https://digitalcommons.law.byu.edu/elj/vol2006/iss2/4 accessed 24 April 2019.

Farrar, J. H. (2018, July). The Future of Australian Legal Education: A Comparative View. In The Future of Australian Legal Education Conference (pp. 143-155). Lawbook Co.

Fereday, J., \& Muir-Cochrane, E. (2006). Demonstrating rigor using thematic analysis: A hybrid approach of inductive and deductive coding and theme development. International journal of qualitative methods, 5(1), 80-92.

Friese, S. (2019). Qualitative data analysis with ATLAS. ti. SAGE Publications Limited, United Kingdom.

Heidi L. Lujan and Stephen E. DiCarlo. (2005). First-year medical students prefer multiple learning styles. Adv Physiol Educ 30: 13-16, 2006; doi:10.1152/advan.00045.2005. 
High, A. (2018). The case for mindfulness in New Zealand legal education. Anna High, "The Case for Mindfulness in New Zealand Legal Education", New Zealand Law Journal [2018], 160-163.

Konopásek, Z. (2007). Making thinking visible with Atlas. ti: Computer assisted qualitative analysis as textual practices. Historical Social Research, Supplement, (19), 276-298.

Mohamad, A. M. (2014). Using ATLAS. ti 7 for researching the socio-legal implications of ICT adoption in the justice system of the high courts of Malaysia, 1st ATLAS.ti User Conference, Berlin, Germany. Online, available at: https://depositonce.tuberlin.de/handle/11303/5140 accessed 10 May 2019.

Ojeh N, Sobers-Grannum N, Gaur U, Udupa A, Majumder MAA. (2017). Learning style preferences: A study of pre-clinical medical students in Barbados. J Adv Med Educ Prof. 2017 Oct; 5(4):185-194.

Paolo A. G. Sivilotti and Scott M. Pike. (2007). The suitability of kinesthetic learning activities for teaching distributed algorithms. In Proceedings of the 38th SIGCSE technical symposium on Computer science education (SIGCSE '07). ACM, New York, NY, USA, 362-366. DOI: https://doi.org/10.1145/1227310.1227438

Peyman, H., Sadeghifar, J., Khajavikhan, J., Yasemi, M., Rasool, M., Yaghoubi, Y. M., Karim, H. (2014). Using VARK Approach for Assessing Preferred Learning Styles of First Year Medical Sciences Students: A Survey from Iran. Journal of clinical and diagnostic research: JCDR, 8(8), GC01-GC4. doi:10.7860/JCDR/2014/8089.4667

Raturi, S. (2018). Understanding Learners'preferences For Learning Environments In Higher Education. The Online Journal of Distance Education and e-Learning, 6(3), 84.

Sarabi-Asiabar A, Jafari M, Sadeghifar J, Tofighi S, Zaboli R, Peyman H, Salimi M, Shams L. (2014). The relationship between learning style preferences and gender, educational major and status in first year medical students: a survey study from iran. Iran Red Crescent Med J. 2014 Dec 27;17(1):e18250. doi: 10.5812/ircmj.18250. eCollection 2015 Jan.

Sherr, A., Moorhead, R., \& Sommerlad, H. (Eds.). (2018). Legal Education at the Crossroads: Education and the Legal Profession. Routledge.

Steven A. Wolfman and Rebecca A. Bates. 2005. Kinesthetic learning in the classroom. J. Comput. Sci. Coll. 21, 1 (October 2005), 203-206

The Certificate IV in Assessment and Workplace Learning: Understanding learners and learning, by Michele Simons, Roger Harris, Erica Smith Research report 17 February 2006 available at https://www.ncver.edu.au/research-and-statistics/publications/allpublications/the-certificate-iv-in-assessment-and-workplace-learning-understandinglearners-and-learning accessed 20 April 2019.

The VARK Modalities (n.d.) online, available at http://vark-learn.com/introduction-tovark/the-vark-modalities/ accessed 3 May 2019. 